\title{
A Study on the Training of Logistics Management Talents in Colleges in the Big Data Age --Taking Luoyang area as an Example
}

\author{
Sijia $\mathrm{Li}^{1 . *}$ and Wenfeng Zhao ${ }^{1}$ \\ ${ }^{1}$ Management Engineering Department, Zhengzhou University, Zhengzhou, China \\ Corresponding Email: 598209309@qq.com
}

\begin{abstract}
Under the background of rapid development in era of Big Data, the logistics industry has become an important service industry to promote economic globalization. This paper explores how colleges and universities to cultivate talents of logistics management in order to better adapted the needs of society.This paper analyzes and summarizes the investigation based on reading relevant literature and using descriptive analysis after investigation. So as to provide some suggestions to the colleges which set up related professional courses of logistics management and the graduates who want to engage in the logistics industry.
\end{abstract}

Keywords. Big Data, talents of logistics management, training mode.

\section{Introduction}

\subsection{Research background}

At this stage of the world is in the era of information explosion.For such complex information, how to better integrate this information is the top priority to win advantage of the era of Big Data, and the logistics industry is one of the representative industries. The logistics industry has become a key to promote China's economic in the context of economic globalization. Therefore, the logistics industry plays a very important role in the development of China's Big Data age.

Data shows that Chinese modern logistics industry has shown a great upward trend, it has a strong market potential and optimistic about the development prospects of the industry. However, there is still a huge supply gap in the supply of professional logistics talent, which has become a short board to limited the development of Chinese logistics industry. Logistics professionals have been listed as one of 12 kinds of scarce talent in China, especially the demand for senior logistics management personnel a serious shortage [1]. However, due to logistics related professional teaching of our country started late, but also the lack of co-ordination arrangements and policies to support the guidance. So,on the whole has not yet entered the track of standardized development. At the same time, most of the community's awareness of the logistics industry still remain in the transport, storage, distribution and other individual aspects, and not have systematic understanding. In now advanced logistics technology of world is not limited to individual aspect, but the unitary plan of the whole process which from the manufacture of products to downstream sales, and which will not only involve the overall operation of the enterprise process but also the number of enterprises coordination and cooperation that related to upstream and downstream. Therefore, the study of logistics personnel's demand situation has become increasingly urgent.

\subsection{Overview of the study}

Chinese logistics industry has great potential and broad prospects, so the domestic scholars began to study after the start of logistics industry developed in China. Pan Wenjun in 2005 pointed out that our country in the logistics management personnel demand analysis on foreign logistics education and logistics personnel training education published research.This aspect of education is not mature, need to be more advanced with the times while strengthening the professional setting and the creation of this professional schools and their respective disciplines combined strengths [2].Wenhua, Wang Ying in 2007 based on the Shenzhen logistics enterprise study the logistics industry demand situation, they believe that with the development of China's logistics industry, logistics enterprises tend to compoundtype, export-oriented and application-oriented talents, while a solid foreign language ability is equally important [3].Gan Hongyun aiming at the contradiction between the training of logistics talents and the demand of enterprises in our country explored the way to solve the problem of how to connect the talent of logistics industry with the demand of enterprises [4].Qu Qunzhen,Ma Jie,Tang Mengxue forecast of logistics talents demand in Shanghai from 2010 to 2015 
by gray system, time series and combination forecasting method [5].Chen Xianyou, Chang Han and other scholars through the field survey, telephone interviews and e-mail and other survey methods of logistics enterprises in Wuhan conducted a demand for talent and logistics management professionals for the development of the recommendations [6].

Lim yu Pui, Dazmin Daud and other scholars using the method of hierarchical regression analysis the needs of logistics practice in the context of the Malaysian colleges and universities by the background of knowledge, skills and talent [7]. In his 2007 survey of CEOs of the top 10 third-party logistics companies,Robert Lieb gained insight into the current state of affairs and explored the future of third-party logistics in the Asia-Pacific region [8]. Matthias Sohn, Werner Sohn and other scholars to explore attracted situation of the logistics talent by logistics company's corporate social performance [9].

China is in the initial stage of logistics management personnel training. The first is that different enterprises have different understanding of logistics management talent.Followed by most of our enterprises are small and medium enterprises, logistics management does not attach importance and those enterprises think logistics management does not need higher education and professional accomplishment. Moreover, the training of logistics management professionals in colleges involves only the cultivation of theoretical knowledge, but the lack of practical training. The final college graduates on their own positioning is not accurate and do not attach importance to grass-roots part of the exercise. They want to become a senior management when they get the job. These have become the logistics professionals' important reasons for the contradiction between supply and demand in China today.

In this paper, based on the situation of Luoyang add up the demand for logistics professionals and the use of gray analysis to predict the next five years of logistics talent demand. In order to promote the establishment of logistics courses in colleges to ease China's logistics professionals supply and demand.

\section{Research design}

\subsection{Sample design}

This survey was conducted in Luoyang by sending a survey questionnaire online, and 70 valid questionnaires were retrieved. The contents of the survey include: the current situation of social demand for various logistics management personnel,logistics management personnel in the enterprise more engaged in the work of enterprises and the community that logistics professionals should have what professional quality, business logistics personnel basic requirements, On the logistics professionals should strengthen what aspects of education and other five elements.

\subsection{Descriptive statistical analysis}

\subsubsection{Current social demand for various logistics management personnel status}

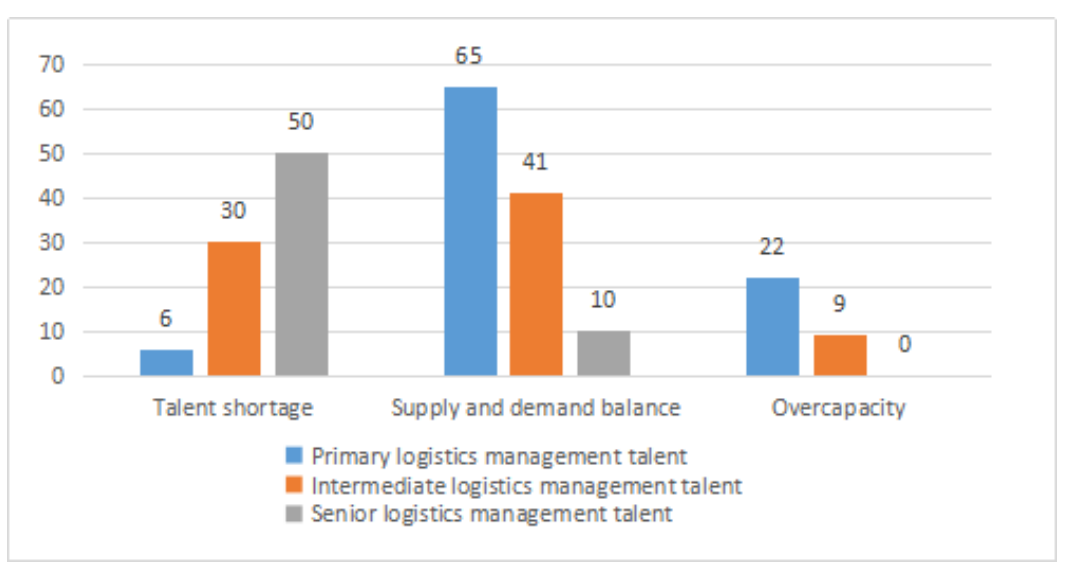

Fig. 1.The demand for logistics management personnel at all levels.

From Figure 1 can be seen that the basic logistics management personnel in the balance of supply and demand, even in some areas in the situation of excess; intermediate logistics management personnel in the three in the middle position, the basic situation is in short supply; and advanced logistics management personnel in the country is in a scarce situation which is serious shortage of talent.Although the major companies hired with high salary, but few candidates.So senior logistics management talent is still the most lacking talent at this stage.

\subsection{2 logistics management personnel in the enterprise more engaged in the work}




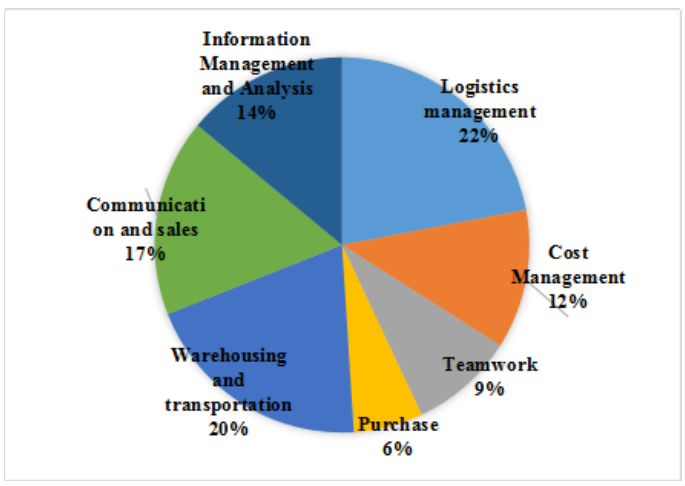

Fig. 2.Logistics management personnel engaged in more work.

Based on the survey of logistics management talented people in Luoyang, it can be seen from Figure 2 that $22 \%$ of the respondents believe that logistics management personnel in the work of more professional work; $20 \%$ of the $9 \%$ of the respondents believe that logistics management is the important factor in logistics management, and logistics management personnel in warehousing, transportation, distribution positions, and followed by communication between customers and sales, information management and analysis, and cost management. $9 \%$ of the respondents believe that talent at work is generally a member of the team to join a project team responsible for logistics work; and fewer people think that logistics management personnel in the procurement position.

\subsubsection{Enterprises and society that logistics management personnel should have what professional quality}

Table1. Logistics management personnel should have the professional quality.

\begin{tabular}{ccc}
\hline Professional knowledge and skills & total & proportion \\
\hline $\begin{array}{c}\text { Logistics management basics } \\
\text { Logistics planning, operational } \\
\text { management knowledge }\end{array}$ & 56 & $80 \%$ \\
$\begin{array}{c}\text { Development and Design of } \\
\text { Logistics Information System } \\
\text { Logistics management software } \\
\quad \text { operation }\end{array}$ & 39 & $55.71 \%$ \\
$\begin{array}{c}\text { Finance, accounting, cost } \\
\text { management }\end{array}$ & 39 & $55.71 \%$ \\
$\begin{array}{c}\text { Management knowledge and skills } \\
\quad \begin{array}{l}\text { Warehousing, inventory, } \\
\text { distribution of knowledge and } \\
\text { skills }\end{array}\end{array}$ & 38 & $55.71 \%$ \\
$\begin{array}{c}\text { Supply chain management } \\
\text { knowledge and skills }\end{array}$ & 27 & $54.29 \%$ \\
$\begin{array}{c}\text { Trade, marketing,business } \\
\text { knowledge }\end{array}$ & 26 & $37.14 \%$ \\
$\quad \begin{array}{l}\text { Foreign language ability } \\
\text { lang }\end{array}$ & 14 & $20 \%$ \\
\hline
\end{tabular}

As can be seen from Table 1, the proportion of the basic knowledge of logistics management with the highest proportion of $80 \%$; logistics planning, operations management knowledge accounted for $60 \%$ of the proportion.As the rapid development of China's information technology, computer technology and widespread Application, logistics information system development and design and logistics management software operation from the beginning of the 21 st century only in large companies and small and medium enterprises are not universal application of the state has become the country's large and small enterprises are almost all in the use.Therefore, the logistics information system development,design and logistics management software operation of the professional requirements in the third and fourth with the proportion was $55.7 \%$. Sixth place is the financial, accounting, cost management, and the proportion is $55.7 \%$. China's enterprises are aware of the logistics management in cost savings and enhance the profits of the huge role, so the logistics management personnel professional quality requirements are also stressed that the use of financial knowledge, or have financial aspects of the work experience.The seventh is management knowledge and skills, accounting for $54.29 \%$. The eighth is the storage, inventory, distribution of knowledge and skills, accounting for $52.86 \%$. Ninth is the supply chain management knowledge and skills, accounting for $38.57 \%$ Chain management is also the 
development trend of China's logistics management at present. Tenth is the trade, marketing, business knowledge, the proportion of $37.14 \%$. While in the final is the foreign language ability, only $20 \%$, which may be due to Luoyang City is located in the Central Plains region, but also is not the first-tier cities in China, so people do not know much about the ability of foreign languages. In Beijing, Shanghai, Guangzhou and other developed first-tier cities, logistics management talents should have the high foreign language level, and generally require a skilled foreign language can be used to read and write.

\subsubsection{The basic requirements of logistics business personnel}

Table2.enterprises of the basic requirements of logistics personnel.

\begin{tabular}{ccc}
\hline Comprehensive quality & total & proportion \\
\hline $\begin{array}{c}\text { Good communication and } \\
\text { communication skills }\end{array}$ & 60 & $85.71 \%$ \\
Love and dedication, loyalty & 58 & $82.86 \%$ \\
Hard-working & 56 & $80 \%$ \\
$\begin{array}{c}\text { Team work } \\
\text { ability }\end{array}$ & 56 & $80 \%$ \\
Proneering and innovative & 54 & $77.14 \%$ \\
$\begin{array}{c}\text { capabilities } \\
\text { Self - learning ability } \\
\text { Social practice ability }\end{array}$ & 51 & $72.86 \%$ \\
$\begin{array}{c}\text { Good physical fitness } \\
\text { Excellent foreign language } \\
\text { skills }\end{array}$ & 27 & $38.57 \%$ \\
\hline
\end{tabular}

The basic requirements of logistics management personnel that is its overall quality requirements. From Table 2 can be seen, good communication and communication skills is the most important logistics management personnel comprehensive quality, the proportion of $85.71 \%$. Good communication ability is the basic ability of every manager necessary. Ranked second in love and respect their jobs, loyalty to the enterprise, accounting for $82.86 \%$, and showing that all companies are employees of the enterprise loyalty is very important.Third is hard-working and hard-working spirit and teamwork, both accounted for $80 \%$, which can be seen in the work of individual hard work and teamwork with others ability to cooperate are very valued enterprises.The fourth is the pioneering and innovative ability, accounting for $77.14 \%$. In today's society, innovation is the most important capacity.It is also important to plan, analyze and understand the tasks assigned by the higher authorities, accounting for $72.86 \%$. The sixth is for the professional knowledge of self-learning ability, the proportion is $50 \%$.Constantly in the work of the professional knowledge to update and learn is also a very important comprehensive quality management. Seventh is the social practice Capacity, accounting for $38.57 \%$, and a manager of the social practice ability is very important, and managers are generally a few years of grass-roots work experience of personnel, so as to be familiar with their own need to manage the project or task exactly what to do,and clear which the experience in this work. Ranked in the latter two were good physical fitness and excellent foreign language level, respectively in $31.43 \%$ and $15.71 \%$.

\subsubsection{Colleges of logistics professionals should strengthen what aspects of education}

Table 3. What kind of education should be strengthened in colleges.

\begin{tabular}{ccc}
\hline Educational direction & total & proportion \\
\hline Logistics management expertise & 57 & $81.43 \%$ \\
Practical ability training & 49 & $70 \%$ \\
\hline
\end{tabular}




\begin{tabular}{lcc}
\hline Computer knowledge and ability & 37 & $52.86 \%$ \\
$\begin{array}{c}\text { Economic management } \\
\text { knowledge }\end{array}$ & 36 & $51.43 \%$ \\
Foreign language ability & 11 & $15.71 \%$ \\
\hline
\end{tabular}

Colleges of logistics management personnel should strengthen what aspects of education survey, the results shown in Table 5. Ranked first is the logistics management expertise, accounting for $81.43 \%$, because now China's logistics professional education theory is not keep pace with the pace of international development, the theory of some outdated and the international advanced logistics management expertise in the introduction and learning is imperative. The second is the practical ability of training, accounting for $70 \%$. China's current emphasis on college education theory teaching, and practice with the actual derailment, resulting in employment difficulties of graduates, enterprises to recruit the right talent is also difficult to embarrassing situation. The third is the computer knowledge and ability, the proportion of $52.86 \%$, the extensive use of computers makes computer knowledge has become an irreplaceable work in today's essential factor. The fourth is the knowledge of economic management, accounting for $51.43 \%$. A certain degree of economic management knowledge and its application to the theory of logistics management in the current stage of economic and trade globalization can make enterprises more competitive. Fifth is the ability of foreign language 15.71\%.In Luoyang, the more information shows that the foreign language ability does not value the situation. However this is not conducive to the development of logistics industry in Luoyang.

\section{Empirical analysis}

As the number of employees in the logistics management industry is scattered and difficult to collect, this paper intends to study the demand of logistics management talents in China in the next five years by calculating the proportion of employees in the logistics management industry in the tertiary industry. Use the data for the next few years to carry out a certain forecast and analysis for the demand for logistics personnel.

Since the number of employees in the tertiary industry is not a quantitative information, and it can not use the quantitative analysis method. So it can use the gray forecast analysis method to forecast it. This paper makes use of the number of employees in the tertiary industry from 2002 to 2014 in the China Statistical Yearbook [10].

Table 4. Number of Employed Persons in the Tertiary Industry in 1997-2014 (Unit: Ten Thousand)

\begin{tabular}{ccccccc}
\hline $\begin{array}{c}\text { year } \\
\text { peopl } \\
\text { e }\end{array}$ & 19432 & 18860 & 19205 & 19823 & 20165 & 20958 \\
\hline $\begin{array}{c}\text { year } \\
\text { peopl } \\
\text { e }\end{array}$ & 2003 & 2004 & 2005 & 2006 & 2007 & 2008 \\
\hline $\begin{array}{c}\text { year } \\
\text { peopl } \\
\text { e }\end{array}$ & 2009 & 2010 & 2011 & 2012 & 2013 & 2014 \\
\hline
\end{tabular}

\subsection{Construction GM $(1,1)$ model}

From $\rho(\mathrm{k})=\frac{x^{(0)}(k)}{x^{(1)}(k-1)}$ we can see, when $\mathrm{k}>3, \rho(k)<0.4$, So quasi-smooth conditions are met.

From $\sigma^{(1)}(k)=\frac{x^{(1)}(k)}{x^{(1)}(k-1)}$ :when $\mathrm{k}>3, \sigma^{(1)}(k) \in(1,1.4), \delta=1.4-1=0.4, \delta \leq 0.5$,So to meet the quasi-exponential law.

The quasi-exponential rule is obtained and the GM $(1,1)$ model is established by using SPSS:

$$
\frac{d x^{(1)}}{d t}-0.044 x^{(1)}=96.504
$$


Correlation test:

$$
\begin{gathered}
\gamma=\frac{1}{n} \sum_{k=1}^{n} \eta(k) \\
\eta(k)=\frac{\min |\varepsilon(k)|+\rho \max |\varepsilon(k)|}{|\varepsilon(k)|+\rho \max |\varepsilon(k)|}(k=1,2,3, \ldots ., n)
\end{gathered}
$$

From $\rho=0.5, \gamma=0.71>0.6$, meet the correlation test.

Relative error test $\Delta(k)=\frac{|\varepsilon(k)|}{x^{(0)}(k-1)} \times 100 \%$, The relevant data into the test $\Delta(k)$ are less than $10 \%$.

Posterior difference test: the standard deviation of the original sequence: $S_{1}=\sqrt{\frac{\sum_{k=1}^{n}\left(x^{(0)}(k)-\bar{X}\right)^{2}}{n}}$

Standard deviation of residual series: $S_{2}=\sqrt{\frac{\sum_{k=1}^{n}(\varepsilon(k)-\bar{\varepsilon})^{2}}{n}}$

According to C, P value to determine the model accuracy, $C=\frac{S_{1}}{S_{2}}$ The relevant data into:

$S_{1}=133.31, S_{2}=14.38$,so $\mathrm{C}=0.13, \mathrm{P}=0.99$. So the accuracy of the above model is reliable.

According to the data published in the China Statistical Yearbook from 2002 to 2014, it can be seen that the employment of the logistics industry accounts for $2.75 \%$ of the total number of employees in the tertiary industry, and the demand is used to calculate the demand,shown in Table 5.

Table 5. Forecast value (Unit: ten thousand).

\begin{tabular}{cccccc}
\hline year & 2015 & 2016 & 2017 & 2018 & 2019 \\
\hline $\begin{array}{c}\text { Gray } \\
\text { model } \\
\text { prediction } \\
\begin{array}{c}\text { Logistics } \\
\text { talent } \\
\text { demand }\end{array}\end{array}$ & 32732 & 34228 & 35165 & 36697 & 38113 \\
\hline
\end{tabular}

\subsection{Analysis of prediction results}

As can be seen from Table 3-2, the demand for logistics talents in the next five years is rising. As the status of the logistics industry in China's economic activities continues to increase [11], the role of the logistics industry in the future is growing. The situation will continue to improve. Although the level of China's logistics industry is uneven and the hardware facilities are not perfect, the logistics industry in China is also developing rapidly. The market demand of logistics management personnel is increasing year by year. The popularity of electronic information technology, supply chain management wide dissemination and the country's logistics personnel to cultivate will accelerate China's logistics industry.

\section{Conclusion and significance}

Through the investigation and research, this paper from the five problems to summarizes the commonness and analyzes the reasons, and to finds out that the logistics-related enterprises pay more and more attention to the comprehensive quality of employees in the background of large data. Because Luoyang in the central plains, the degree of openness than the coastal and first-tier cities, so the level of foreign language requirements are not prominent. But in the context of China's great times, foreign language applications more widely, and has become an important indicator of comprehensive strength. Based on this strengthening foreign language skills for the mainland students to coastal cities and first-tier cities, and even overseas work is particularly important.

In background of Big Data, the senior logistics management talent is most scarce of the market demand. But because of the job candidates personal capacity, work experience, the overall planning and integration capacity is high, so the 
candidates are few. Due to the huge data information needs to be dealt with, the demand for logistics management talents in enterprises at this stage is more and more inclined to compound talents. Logistics management personnel in the complex talents such as proficient in the logistics management expertise at the same time familiar with economic and financial knowledge; proficient in logistics management expertise at the same time familiar with computer information technology knowledge; proficient in logistics management expertise at the same time familiar with legal knowledge and so on, these are the focus of the compound talents in the demand for talent in the modern enterprise increasingly sought-after.

In the logistics management professionals of the professional and comprehensive quality requirements can be seen that the higher the level of talent in their logistics expertise should be have the ability to request the higher, meanwhile on the computer level, information management, foreign language level and so on has a very high demand. Therefore, logistics students in order to adapt to the era of large data background in the four-year undergraduate study should also focus on strengthening their ability in these areas, in order to meet the needs of the community to improve their own quality.

In the logistics management personnel engaged in the investigation of the work point of view. Most are engaged in logistics management and related departments. At the context of China's large data logistics, management talent in the future direction of development and development of view: more and more enterprises are willing to outsource their own logistics module, so professional third-party logistics business prospects are good, and these enterprises are also need more and more logistics management talents. With the rapid development of supply chain management in China, many large enterprises have begun to consider the transformation and upgrading for the establishment of a complete supply chain management system, and logistics management as a supply chain management is very important, so the future prospects are also optimistic, which also requires the future of logistics management personnel with knowledge of logistics management should also have knowledge of supply chain management.

This paper uses the gray forecast analysis method to establish the model, predicts the demand situation of the logistics talents in the next five years, and obtains that the demand situation of the logistics management talent is good in the next five years. The demand potential is also relatively large.

Due to the limitation of personal knowledge and time, there are still many shortcomings in the investigation and research on the demand of logistics management talents. The depth and breadth of the research are still to be expanded. Something need to in-depth study of the content: 1 more enterprises should be surveyed which will making the data more reliable. 2 it can be added such as time series forecasting methods to predict the number of the next few years, making the conclusion more credible and accurate.

\section{References}

1. Zou Min, Xie Ming, LI Ying. Discussion on the Development of Logistics Management Specialty and the Demand of Talents in Higher Vocational Colleges - The Investigation Report on the Status Quo of Hunan Logistics Enterprises and the Demand for Talents.Fourth Industrial Enterprise Logistics Forum Proceedings, 2007,26 (8): 65-67.

2. Pan Wenjun.Gap_Status_Strategy - Foreign Logistics Education and Logistics Personnel Training in China.China Logistics \& Purchasing, 2005 (14): 70-72.

3. Wen Hua, Wang Ying. From the needs of enterprises to see the logistics management professional bilingual teaching. Higher Education Exploration, 2007 (6): 152-155.

4. Gan Hongyun. Discussion on the Effective Docking between Logistics Talents Training and Enterprise Demand in China.Journal of Logistics Engineering and Management, 2009,31 (7): 139-140.

5. Qu Qunzhen, Ma Jie, Tang Mengxue. Shanghai $2010 \sim 2015$ years of logistics talent demand forecast and countermeasures research modern management science, 2011 (10): 115-117.

6. Chen Xian-you, Chang Han, Li Jun, Wen Qiqi.The investigation and analysis of enterprises' demand for logistics management talents.Technology Start Monthly, 2013 (4): 45-47.

7. Lim Yu Pei, Dazmin Daud, Kholyn Ruran Jonathan. Perceptions of Logistics Students on Internship Programme: The Case of Private Higher Institution in Malaysia. Canadian Social Science,2012,8 (4) :1-7.

8. Robert Lieb. The year 2007 survey: Provider CEO perspectives on the current status and future prospects of the third party logistics industry in the Asia-Pacific region. International Journal of Physical Distribution \& Logistics Management,2008,38(6):220-224.

9. Matthias Sohn,Werner Sohn,Thorsten Klaas-Wissing,Bernhard Hirsch.The influence of corporate social performance on employer attractiveness in the transport and logistics industry. International Journal of Physical Distribution \& Logistics Management,2015,45 (5) :486-505.

10. China National Bureau of Statistics. China Statistical Yearbook .2006, 2007, 2008, 2009, 2010, 2011, 2012, 2013, 2014.

11. Li Guanyi.Electronic business logistics innovation and traditional logistics transformation under the Internet.Commercial Research,2016(4):187-192. 